\title{
INTRODUCTION TO THE SYMPOSIUM ON ZACHARY MOLLENGARDEN \& NOAM ZAMIR “THE MONETARY GOLD PRINCIPLE: BACK TO BASICS”
}

\author{
Dapo Akande*
}

It has been stated that it is a "truism that international judicial jurisdiction is based on and derives from the consent of states." 1 While the manner in which that consent may be given varies-from ad hoc consent given with respect to the particular dispute in question, to consent over any dispute arising under a particular treaty, and even to broad acceptance of the so-called "compulsory jurisdiction" of the $\mathrm{ICJ}^{2}$ - the requirement of consent is invariable. All international tribunals which exercise competence over disputes involving states require the consent of those states for the state to be a party to proceedings before the tribunal.

While the consent principle ensures that parties to inter-state cases before international tribunals must have accepted the jurisdiction of the tribunal to rule on the case, the principle has also been applied more broadly. The ICJ has decided that it is precluded from exercising its jurisdiction even where the parties have consented but where to do so would require adjudication of the legal interests of a third state that is not a party to the case and has not given consent to the Court determining the matter. ${ }^{3}$ This principle, known as the Monetary Gold doctrine, requires the Court to abstain from deciding a case only where the legal interests of a non-consenting third state forms "the very subject matter" of the case, ${ }^{4}$ and where the Court cannot decide the case before it without adjudicating on the international responsibility (or the rights) of a third state.

In their article, Zachary Mollengarden \& Noam Zamir revisit the doctrinal and policy arguments for the Monetary Gold doctrine. The timing of their piece could hardly have been better. In the weeks after their piece was published, both a Special Chamber of the International Tribunal for the Law of the Sea (ITLOS) ${ }^{5}$ and the Pre-Trial Chamber of the International Criminal Court ${ }^{6}$ were faced with decisions as to whether to apply the doctrine. There is an increasing tendency for international disputes to move beyond the bilateral framework that

* Professor of Public International Law \& Co-Director, Oxford Institute for Etbics, Law and Armed Conflict, University of Oxford; Fellow, Exeter College, Oxford, United Kingdom.

${ }^{1}$ Hugh Thirlway, The Law and Procedure of the International Court of Justice 1960-1989 (Part Nine), 69 BRIT. Y.B. IN’T L. 1, 4 (1998).

2 See Statute of the International Court of Justice art. 36(2). Consent is regarded as so important within the context of the ICJ that states are entitled to restrict the general scope of jurisdiction of the Court by entering reservations to the declarations they make accepting the Court's compulsory jurisdiction. Other international courts that operate a similar system by which states make declarations accepting the jurisdiction of the court have not accepted that states making such a declaration can restrict their general consent by making reservations. See also Loizidou v. Turkey (1995) 20 EHRR 99.

${ }^{3}$ Monetary Gold Removed from Rome in 1943 (It. v. Fr., U.K. \& U.S.), 1954 ICJ Rep. 19 (June 15). See also East Timor (Port. v. Austl.), 1995 ICJ REP. 90 (June 30).

${ }^{4}$ Monetary Gold Removed from Rome in 1943 (It. v. Fr., U.K. \& U.S.), 1954 ICJ ReP. 19, 33 (June 15).

${ }^{5}$ Dispute Concerning Delimitation of the Maritime Boundary Between Mauritius and Maldives in the Indian Ocean, Preliminary Objections, Judgment (ITLOS, Jan. 28, 2021).

${ }^{6}$ Decision on the 'Prosecution Request Pursuant to Article 19(3) for a Ruling on the Court's Territorial Jurisdiction in Palestine', ICC01/18, paras. 58-60 (Feb. 5, 2021).

(C) Dapo Akande 2021. This is an Open Access article, distributed under the terms of the Creative Commons Attribution licence 140 (http://creativecommons.org/licenses/by/4.0/), which permits unrestricted re-use, distribution, and reproduction in any medium, provided the original work is properly cited. 
international adjudication seems to be particularly designed for, and to include multilateral features. The question of how courts, particularly the ICJ, can deal with such multilateral disputes, where two but not necessarily all of the states involved in the dispute have consented to the court's jurisdiction, invites examination or re-examination of the Monetary Gold doctrine.

This increasing multilateral nature of international disputes arises, in part, from the increasing recognition in international law that states may act to vindicate not just their own interests but also broader community interests. As they seek to do so before international tribunals, such claims may raise questions about whether the decision of the tribunal would require adjudication of the responsibilities or rights of absent third states. The East Timor case, where Portugal was seeking to vindicate the right to self-determination of the people of East Timor, and Australia successfully invoked the Monetary Gold doctrine, foreshadows this problem even though Portugal brought the claim as the administering authority rather than as a third party seeking to enforce erga omnes obligations. ${ }^{7}$

Mollengarden and Zamir argue that the Monetary Gold doctrine ought to be abandoned. In their view, the doctrine is incompatible with the "jurisdictional architecture" of the ICJ's Statute. They argue that the Court's jurisdiction is based on the consent of the parties, but the doctrine "privileges the consent of absent third parties and thereby improperly directs the Court to refuse to decide cases over which it has jurisdiction."

The argument that the Court ought to give overriding effect to the jurisdictional link created by the consent of the parties ignores (i) the point that the Court's Statute should be interpreted in the light of general international law, and (ii) the fact that the consent principle, from which the Monetary Gold doctrine is derived, is itself derived from the principles of sovereign equality and independence. ${ }^{9}$ Sovereign equality reflects the idea, which is fundamental to international law as currently conceived, that states are not in principle (at least when they act in the exercise of sovereign authority) subject to the legal authority of other states. The principle of independence means that states are not subject to external obligations or imposition of external authority unless the state has accepted those obligations. Since international tribunals are creations of states, to accept that such tribunals can exercise authority over states that have not consented to the exercise of such authority would seem to be a violation not only of the principle of independence but also that of sovereign equality. If these points are correct, the question that is left for consideration is whether, by making a decision on the rights or responsibilities of a state in a case where that state is not a party, the ICJ is to be considered as exercising authority over that state.

While the authors of the lead article around which this symposium is organized focus on the jurisdictional framework of the ICJ as established by its Statute, the Court itself has sought to place that Statutory framework within the broader frame of international law principles. In the Monetary Gold case, the ICJ spoke of "a well-established principle of international law embodied in the Court's Statute". ${ }^{10}$ That statement recalled the earlier statement of the Permanent Court of International Justice (PCIJ) in the Eastern Carelia Advisory Opinion which draws from beyond the Court's Statute in pointing out that: "It is well established in international law that no State can, without its consent, be compelled to submit its disputes with other States either to mediation or to arbitration, or to any other kind of pacific settlement." ${ }^{11}$ Indeed, the ICJ has even gone further and in the Western Sabara Advisory

${ }^{7}$ East Timor (Port. v. Austl.), Judgment, 1995 ICJ Rep. 90 (June 30). See also Obligations Concerning Negotiations Relating to Cessation of the Nuclear Arms Race and to Nuclear Disarmament (Marsh. Is. v. U.K.), Preliminary Objections, 2018 ICJ ReP. 833 (Oct. 5) where the question of the Monetary Gold doctrine would likely have become important had the Court proceeded to the merits. See particularly the Separate Opinion of Judge Tomka (paras. 38-42) and the Dissenting Opinion of Judge Crawford (paras. 32-33).

${ }^{8}$ Zachary Mollengarden \& Noam Zamir, The Monetary Gold Principle: Back to Basics, 115 AJIL 41, 43 (2021).

${ }^{9}$ On sovereign equality, see Colin Warbrick, The Principle of Sovereign Equality, in The United Nations and the Principles of International Law: Essays in Memory of Michael Akehurst 204 (Warbrick \& Lowe eds., 1994).

${ }^{10}$ Monetary Gold Removed from Rome in 1943 (It. v. Fr., U.K. \& U.S.), 1954 ICJ Rer. 19, 32 (June 15).

${ }^{11}$ Status of Eastern Carelia, Advisory Opinion, 1923 PCIJ (ser. B) No. 5, at 27 (July 23). 
Opinion, referred to "the fundamental rule, repeatedly reaffirmed in the Court's jurisprudence, that a State cannot without its consent, be compelled to submit its disputes with other States to the Court's adjudication."12 Moreover, in the Eastern Carelia case, the PCIJ linked the consent principle to "a fundamental principle of international law, namely, the principle of the independence of States." ${ }^{\prime 3}$ It is the fundamental nature of the consent principle which suggests that adjudication without consent cannot occur even in cases where the state whose rights or obligations are being adjudicated upon is not a party to the case. ${ }^{14}$

That the Monetary Gold doctrine reflects more general principles of international law can be seen from the fact that, as Martins Paparinskis points out in this Symposium, ${ }^{15}$ a number of other international tribunals have referred to it approvingly. However, it is equally true that the doctrine has rarely been applied by other tribunals to dismiss a claim.

The essays in this symposium address the spectrum of issues covered by Mollengarden and Zamir, engaging with their doctrinal analysis as well as their policy arguments. In her essay, Juliette McIntyre takes on the point made by Mollengarden and Zamir that the Monetary Gold doctrine is to be treated merely as a "judicial decision" and thus as a subsidiary source to which little deference should be given. ${ }^{16}$ She argues that the best way to understand the principle from that decision is to regard it as a rule of procedure emerging from the ICJ's power under its Statute to construct rules of procedure. In her view, while the Court will typically promulgate formal Rules of Procedure, it may also, and has historically, articulated procedural rules in the context of particular cases. Such rules, though emerging from the case law, are, she argues, entitled to be regarded as having normative authority exceeding that of mere judicial decisions.

As a doctrinal matter, Pierre d'Argent argues that the Monetary Gold principle does not go to whether the ICJ has jurisdiction but rather to the exercise of that jurisdiction. ${ }^{17}$ In his view, the principle is not about whether the Court can hear a case but rather about whether it can entertain particular claims. Unlike the authors, he argues that reliance on intervention by third parties would not solve the problems that the Monetary Gold principle is designed to address.

While Paparinskis is unpersuaded by Mollengarden and Zamir's doctrinal arguments for abandoning the Monetary Gold doctrine he notes that one may be sympathetic to their policy concerns about its implications for complex multilateral disputes. In his view, there is scope to examine how application of the doctrine might leave room for credible engagement by the Court with such disputes. Indeed, he argues that the Court's jurisprudence is not insensitive to or necessarily incompatible with multilateral disputes. He briefly discusses the important point of when a tribunal may choose not to apply the doctrine and may go on to decide a claim involving the rights or responsibilities of an absent third party, on the basis of prior decisions by an international institution which may be taken as "givens" in the context of the dispute.

The reference to "givens" is to the exception to the Monetary Gold principle established by the arbitral tribunal in Larsen v. Hawaiian Kingdom, where it was stated that "if the legal finding against an absent third party could be taken as a given (for example, by reason of an authoritative decision of the Security Council on the point), the [Monetary

\footnotetext{
${ }^{12}$ Western Sahara, Advisory Opinion, 1975 ICJ Rep. 12, 23 (Oct. 16).

13 Status of Eastern Carelia, Advisory Opinion 1923 PCIJ (ser. B) No. 5, at 27 (July 23).

${ }^{14}$ Chittharanjan Felix Amerasinghe, Jurisdiction of International Tribunals 74 (2003).

15 Martins Paparinskis, Long Live Monetary Gold *Terms and Conditions Apply, 115 AJIL Unbound 156, n. 12 (2021). It should be noted that the International Criminal Court's Pre-Trial Chamber in the Palestine decision, supra note 6 held that the doctrine does not apply to the International Criminal Court.

${ }^{16}$ Juliette McIntyre, Rules are Rules: Reconceiving Monetary Gold as a Rule of Procedure, 115 AJIL Unbound 144 (2021).

${ }^{17}$ Pierre d'Argent, The Monetary Gold Principle: A Matter of Submissions, 115 AJIL Unbound 149 (2021).
} 
Gold principle may well not apply." 18 The basis of this assumption is that if the international tribunal is simply applying a legal finding which is already binding or authoritative with respect to the third state there can be no complaint of an overreach of competence as the tribunal is not really exercising its own competence but simply accepting a reality already determined by a competent body. It is precisely this point that was in issue in Mauritius/ Maldives where the ITLOS Special Chamber considered that the ICJ's Chagos Advisory Opinion and the UN General Assembly Resolutions recognizing that Opinion, provided sufficient legal basis for ITLOS to decide that it was Mauritius and not the United Kingdom (an absent third party in the ITLOS proceedings) that has sovereignty over the Chagos archipelago. ${ }^{19}$ Although the particular application of this exception to advisory opinions has been criticized by some, ${ }^{20}$ the existence of the exception is one example of how the Monetary Gold doctrine does not, in appropriate cases, preclude adjudication of cases involving the legal interests of absent third parties.

Florencia Montal's essay addresses one policy argument that may be made for sticking with the Monetary Gold doctrine - that reliance on state consent is likely to engender greater compliance for ICJ decisions and corresponding greater legitimacy. ${ }^{21}$ In her essay, she examines the link between consent to the jurisdiction of international tribunals and the question of state compliance with the decisions of such tribunals. She argues that while consent may be indicative of a state's willingness to abide by a decision, reliance on state consent will not necessarily lead to greater compliance with decisions since what is more important is how the decision links to broader political bargains.

In her essay, Beatrice Bonafé explores the ways in which community interests have been taken into account in the system of international adjudication, which typically deals with disputes with a bilateral character. ${ }^{22}$ She describes the procedural tools for accommodating multilateral disputes and the ways in which relations engendered by community interests are bilateralized. She carefully considers the "logic of inclusion" that is inherent in joinder of cases and intervention in cases as permitted by the ICJ Statute. However, she also identifies a "logic of isolation" by which, in cases involving community interests, "the legal relationship between the entire community and the author of the breach is dissolved into a bundle of relations between each member of the community and the latter." In so doing, it is possible to bilateralize a matter that in reality has a broader frame of reference.

Collectively, these essays contribute to the debate initiated by Mollengarden and Zamir on whether international courts, in particular the ICJ, should abandon, revise, or rethink the basis and application of the Monetary Gold principle.

18 Larsen v. Hawaiian Kingdom, 119 ILR 566, 592, para. 11.24 (2001).

19 Dispute Concerning Delimitation of the Maritime Boundary Between Mauritius and Maldives in the Indian Ocean, Preliminary Objections, Judgment (ITLOS, Jan. 28, 2021).

20 See Sarah Thin, The Curious Case of the Legal Effect' of ICJ Advisory Opinions in the Mauritius/Maldives Maritime Boundary Dispute, EJIL:TALK! (Feb. 5, 2021).

${ }^{21}$ Florencia Montal, Does Consent Engender Compliance? Insights from Empirical Research on International Tribunals, 115 AJIL UNBOUND 160 (2021).

${ }^{22}$ Beatrice I. Bonafè, Adjudicative Bilateralism and Community Interests, 115 AJIL UnBound 164 (2021). 